\title{
The Relationship between Pre-Service Early Childhood Teachers' Environmental Education Self-Efficacy Beliefs and Their Attitudes towards Sustainable Environment
}

\author{
Turan GÜLÇiçEK ${ }^{1}$
}

Gönderim Tarihi: 23.03.2021

Kabul Tarihi: 20.08 .2021

Yayın Tarihi: 19.10 .2021

\begin{abstract}
The main purpose of this study is to examine the relationship between pre-service early childhood teachers' environmental education self-efficacy beliefs and their attitudes towards sustainable environment. This research was conducted with a total of 129 pre-service early childhood teachers in a public university of Ankara, Turkey. To collect the data of pre-service teachers' attitudes toward sustainable environment, Sustainable Environment Attitude Scale (SEAS) was employed. Besides, Environmental Education Self-Efficacy Scale (EESS) was used to identify pre-service teachers' selfefficacy beliefs about environmental education. To analyze the data, independent sample t-test analysis was conducted for comparison of groups. Moreover, one-way analysis of variances (ANOVA) was executed for contrasting groups in terms of grade level. Lastly, the Pearson's correlation was employed to investigate the relationship between environmental education self-efficacy beliefs and sustainable environment attitudes. Results showed that there is a statistically significant relationship between pre-service teachers' environmental education self-efficacy beliefs and their attitudes toward sustainable environment.
\end{abstract}

Keywords: Early childhood education, Environmental education in early childhood education, Sustainability in early childhood education, Self-efficacy beliefs of pre-service early childhood teachers.

\section{Okul Öncesi Öğretmen Adaylarının Çevre Eğitimi Öz-Yeterlik İnanışları ve Sürdürülebilir Çevreye Yönelik Tutumları Arasındaki İlişki}

Öz: Bu çalışmanın amacı okul öncesi öğretmen adaylarının çevre eğitimi öz-yeterlik inanışları ve sürdürülebilir çevreye karşı tutumları arasındaki ilişkiyi incelemektir. Araştırmanın örneklemini Ankara'da devlet üniversitesinde öğrenim görmekte olan 129 öğretmen adayı oluşturmaktadır. Öğretmen adaylarının sürdürülebilir çevreye karşı tutumlarını ölçmek için Sürdürülebilir Çevre Tutum Ölçeği, çevre eğitimi öz-yeterlik inanışlarını ölçmek için ise Çevre Eğitimi ÖzYeterlik Ölçeği kullanılmıştır. Araştırmanın analizinde grupları karşılaştırmak için bağımsız örneklerim $t$ testi ve tek yönlü varyans analizi (ANOVA) kullanılmıştır. Pearson korelasyon analizi ile çevre eğitimi öz-yeterlik inanışları ve sürdürülebilir çevreye karşı tutumları arasındaki ilişkiye bakılmıştır. Verilerin analizi sonucunda, öğretmen adaylarının çevre eğitimi öz-yeterlik inanışları ve sürdürülebilir çevreye karşı tutumları arasında istatistiksel olarak anlamlı bir ilişki saptanmıştır.

Anahtar Kelimeler: Okul öncesi eğitimi, Okul öncesinde çevre eğitimi, Okul öncesinde sürdürülebilirlik, Okul öncesi öğretmen adaylarının öz-yeterlik inanışları.

\section{INTRODUCTION}

Early childhood years play a crucial role in an individual's life because the most crucial developments occur in this period (Mustard, 2000; Rutter, 2002). Early childhood education which provides a basis for all developmental areas and a lifelong learning, leads to progress of attitudes, behaviors and skills (Pearson \& Degotardi, 2009; Ernst \& Tornabene, 2012). Moreover, a growing body of research from various fields such as economics, neuroscience reveal that investments into early childhood education are redeemable for the benefits of people and broader community in later years (Davis, 2009). Early childhood education consists of many fields including environmental education which deals with incorporating young children into environmental learning through interacting with nature (Duhn, 2012). However, young children have been less likely to spent time with nature recently because early childhood teachers have inadequate experiences in nature and when teachers have inadequate experiences, they might be unwilling to have children interact with

\footnotetext{
${ }^{1}$ Karamanoğlu Mehmetbey Üniversitesi, Türkiye, turangulcicek@kmu.edu.tr, ORCID: 0000-0002-5987-0401
} 
environment or nature (Crim, Desjean-Perrotta, \& Moseley, 2008). With respect to this issue, Evans, Whitehouse and Hickey (2012) argued that teachers' beliefs, knowledge and their thinking influence the content of teaching and teachers are disposed to teach the issue that they are authority on and interested in.

Although there is a growing disposition for involving children into nature, there is a limited research about early childhood environmental education and education for sustainability (Davis, 2009). In addition, Torquati, Cutler, Gilkerson, \& Sarver (2013) asserted that there is limited information regarding early childhood educators' knowledge, attitudes and confidence how to implement environmental education.

\section{Sustainability in Early Childhood Education}

Sustainability is perceived as comprehensive understanding of relationships and interconnections between people, environment, culture and space (Duhn, 2012 \& Liu, 2011). For early childhood education, it includes obtaining conceptual understanding about sustainability and environment. Besides, it involves skills that are being respectful for species and the life (Independent Earth Charter Commission 2012; Brundtland 1987). Sustainability is not an issue that can be overlooked because the world has been subject to significant challenges such as climate change, loss of species, deforestation and those problems can be eliminated by the collaboration of sustainability and education. Although primary and secondary education have been engaged with sustainability for a long time, early childhood education is a new field for sustainability (Dyment, Davis, Nailon, Emery, Getenet, McCrea, \& Hill, 2014). Furthermore, Davis (2009) stated that there is a research deficiency in early childhood education for sustainability and environmental education. As such, Davis (2009) determined that neither have early childhood education researchers focused their attention on sustainability/environmental issues nor have environmental researchers engaged with early childhood education.

With regards to teachers, Symons (2008) revealed that teachers are lacking in knowledge about sustainability issues because of their inadequate training in their undergraduate education which ultimately lead to a significant obstacle for the implementation of the sustainability. Likewise, the study conducted by Cutter-MacKenzie and Smith (2003) found that primary teachers had poor understanding about environmental issues and also $85 \%$ of participants being surveyed in this study expressed that they did not have formal training about environmental issues at university. Accordingly, Evans et al. (2012) argue that pre-service teachers need to graduate with knowledge how to incorporate environmental and sustainability education into their profession by including environmental/sustainability education into their teacher training program. In addition to this, the research conducted by Ull, Martínez-Agut, Piñero and Aznar-Minguet (2014) about perceptions and attitudes of pre-service teachers revealed that $75 \%$ of participants are not aware of the effect of their daily routines on environment. Related to this, Tomas and Mills (2011) contended that pre-service teachers need to assure themselves in sustainable issues because being concerned about environment is not enough to implement those issues into classrooms (As cited in Tomas et al., 2015).

Effeney and Davis (2013) revealed that most of teachers are concerned about their level of understanding of sustainability concepts but more experienced teachers think that sustainability is significant for education. It was also found that teachers believe that education for sustainability is crucial and they are assertive for their skills in engagement of education for sustainability. Besides, this study revealed that there is a statistically significant positive relationship between teachers' perceived knowledge and efficacy for teaching sustainability. In other words, the more level of 
knowledge teachers have, the more self-efficacy teachers have. Lastly, Ballantyne and Packer (2005) argue that teachers need to engage with sustainability concepts in order to have more positive attitudes towards sustainability.

\section{Early Childhood Environmental Education}

Environmental education is defined as developing individuals' environmental consciousness, protecting natural, historical, cultural and socio-aesthetic values by getting individuals gain positive and permanent behavioral changes and lastly, providing active participation in solution of the problems (Under secretariat of environment, 1990). Early childhood environmental education term is a combination of early childhood education and environmental education (Boileau, 2013). The North American Association for Environmental Education [NAAEE] states that environmental education in early childhood is an integral concept which comprises understanding of the natural world along with skills, emotions and dispositions (2010). Furthermore, according to Wilson (2009), respect for the other entities, development of the curiosity, appreciating natural world for its beauty and mystery are also involved in early childhood environmental education.

Environmental education is a significant learning area for early childhood education and also the significance of early childhood education is clear and accepted in environmental education field (Pearson \& Degotardi, 2009). Environmental education has some benefits for children. That is, environmental concern and a healthy relationship with the environment can be provided with the help of early environmental experiences. When those experiences are inadequate, children become alienated from the natural world (Boileau, 2013). In addition to this, environmental education helps children to improve their naturalistic intelligence which means "the ability to recognize and classify plants, minerals, and animals including rocks and grass and all variety of flora and fauna" (Checkley, 1997). Also, natural environment is beneficial for children's development and well-being. That is, environment and sustainability-based activities improve children's academic achievement (Torquati et al., 2013).

Children make an attachment with natural world when they show respect to it. Besides, after they comprehend the connection between themselves and the nature, children will become environmentally literate citizens. In this period, environmental education strengths the link between children and natural world (NAAEE, 2010). In environmental education, teachers play a very crucial role. However, Louv (2008) claims that many teachers have inadequate experiences with nature since those teachers are the generations spending limited time outdoors. Additionally, it is common that people with limited experience in nature indicate anxiety and discomfortable feeling when they are in natural areas (Bixler, Carlisle, Hammitt, \& Floyd, 1994). Furthermore, teachers are not certain about how to use natural environment in their teaching. To illustrate, teachers indicated low selfesteem and they required training in order to teach environmental education concepts (Simmons, 1998). Another study conducted by Ernst \& Tornabene (2012) found that pre-service early childhood teachers are not willing to prefer natural outdoor areas for educational purposes because they think that those areas have nothing to do with early childhood education.

\section{Purpose of the Study}

The main purpose of this study is to analyze relationship between pre-service early childhood teachers' self-efficacy beliefs for environmental education and their attitudes towards sustainable environment. Moreover, this study aims at investigating pre-service early childhood education teachers' self-efficacy beliefs for environmental education and their attitudes towards sustainable environment by answering following research questions; 
(1) Is there a significant difference in pre-service early childhood education teachers' environmental education self-efficacy beliefs regarding taking environmental education course or not in Turkey?

(2) Is there a significant difference in pre-service early childhood education teachers' attitudes towards sustainability environment with respect to having sustainability course or not in Turkey?

(3) Is there a significant difference in pre-service early childhood teachers' environmental education self-efficacy beliefs with respect to grade level in Turkey?

(4) Is there a significant difference between pre-service early childhood teachers' sustainable environment attitudes in terms of grade level in Turkey?

(5) Is there a relationship between pre-service early childhood teachers' environmental education self-efficacy beliefs and their attitudes towards sustainable environment in Turkey?

\section{METHOD}

\section{Design of the Study}

Fraenkel, Wallen and Hyun (2013) claims that correlational research examine the possibility of relationship between two or more variables without manipulation of variables and correlational research is a form of descriptive research because it identifies an existing relationship between variables. Moreover, correlational research aims at defining the degree to which two or more quantitative variables are related by utilizing a correlation coefficient (Fraenkel, Wallen, \&Hyun, 2013). Thus, because this study examines the relationship between pre-service early childhood teachers' self-efficacy beliefs for environmental education and their attitudes towards sustainable environment, this study is a correlational research based on the definition above.

\section{Population and Sampling}

Population of the study is all pre-service early childhood teachers studying in public universities in Ankara. Because it is not feasible to reach all pre-service teachers in Ankara, a sample group was selected for the purpose of this inquiry. For sampling of this study, convenience sampling procedure was preferred. More precisely, a state university in Ankara, Turkey which was convenient to the researcher was selected to collect data of this inquiry. Participants consisted of 129 pre-service teachers in the department of Early Childhood Education of that university of Ankara, Turkey. Of the 129 participants, $24(18.6 \%)$ are freshmen, 31 (24.0\%) are sophomore, 42 (32.6\%) are junior, and $32(24.8 \%)$ are senior students.

The following part presents the results of demographic information of participants. In relation to this aim, grade level and the number of participants taking environmental and sustainability education course or not are presented in Table 1 and Table 2.

Table 1. Demographics of the Study Participants.

\begin{tabular}{|c|c|c|c|c|}
\hline $\begin{array}{l}\text { Grade } \\
\text { Level }\end{array}$ & $\begin{array}{l}\text { Number of } \\
\text { Participants } \\
\text { Taking } \\
\text { Environmental } \\
\text { Education Course }\end{array}$ & $\begin{array}{l}\text { Number of } \\
\text { Participants Not } \\
\text { Taking } \\
\text { Environmental } \\
\text { Education Course }\end{array}$ & Total & $\%$ \\
\hline 1th Grade & 0 & 24 & 24 & 18.6 \\
\hline 2nd Grade & 1 & 30 & 31 & 24.0 \\
\hline 3rd Grade & 2 & 40 & 42 & 32.6 \\
\hline 4th Grade & 6 & 26 & 32 & 24.8 \\
\hline
\end{tabular}


Table 2. Demographics of the Study Participants.

\begin{tabular}{|c|c|c|c|c|}
\hline $\begin{array}{l}\text { Grade } \\
\text { Level }\end{array}$ & $\begin{array}{l}\text { Number of } \\
\text { Participants } \\
\text { Taking } \\
\text { Sustainability } \\
\text { Course }\end{array}$ & $\begin{array}{l}\text { Number of } \\
\text { Participants Not } \\
\text { Taking } \\
\text { Sustainability } \\
\text { Course }\end{array}$ & Total & $\%$ \\
\hline 1th Grade & 2 & 22 & 24 & 18.6 \\
\hline 2nd Grade & 0 & 31 & 31 & 24.0 \\
\hline 3rd Grade & 3 & 39 & 42 & 32.6 \\
\hline 4th Grade & 13 & 19 & 32 & 24.8 \\
\hline
\end{tabular}

As results suggest, students who have taken environmental education or sustainability education courses are very few compared to students who have not taken environmental education or sustainability education courses in the course of examination of the results, the number of students experienced environmental education is $9(N=9)$ in total. Also, there are 18 students $(N=18)$ who have taken sustainability education course in all grades.

\section{Data Collection Instruments}

In order to determine pre-service early childhood teachers' attitudes toward sustainable environment, Sustainable Environment Attitude Scale (SEAS) developed by Yildiz (2011) was utilized. The SEAS consists of 27 items in the form of five-point Likert scale. For the reliability of this scale, Cronbach a is calculated as .89 which indicates that this scale has a significant reliability. On the other hand, to identify pre-service early childhood teachers' self-efficacy beliefs about environmental education Environmental Education Self-Efficacy Scale (EESS) was used. Özlü, Keskin and Gül (2013) developed the scale with 24 items in the form of five-point Likert scale. For the internal consistency of this scale, Cronbach a value was determined as .97 which means that this scale also has a significant reliability.

\section{Data Analysis}

The data of this study was analyzed by utilizing IBM® SPSS Version 24 software. In the course of investigation, descriptive statistics were employed to examine demographic information of participants. For a convenient analysis of results, mean scores of SEAS and EESS were calculated first. Following Shapiro-Wilk test assuming the normal distribution of datasets ( $p>.05)$, independent sample t-test analysis was conducted for comparison of groups. Moreover, one-way analysis of variances (ANOVA) was executed for contrasting groups in terms of grade level. In addition to this, Scheffe test was conducted for significant $\mathrm{F}$ values in order to comprehend the source of significance. Lastly, the Pearson's correlation was employed to investigate the relationship between environmental education self-efficacy beliefs and sustainable environment attitudes. As it is seen, parametric tests were used to analyze the data although the data were obtained through a Likerttype scale which provides ordinal data. With regard to this, De Winter and Dodou (2010) claimed that when there are Likert data, we need to conduct both parametric and non-parametric alternative tests and if results of both tests are the same, it does not matter which of the two statistical analysis are used to analyze Likert data. As a result, Mann-Whitney U Test and Kruskal-Wallis Tests which are non-parametric alternatives of Independent-samples $t$ test and one-way ANOVA respectively are conducted. Because both non-parametric tests provided the same results with parametric tests, parametric tests were performed in this study. 


\section{RESULTS}

To investigate whether there is a significant difference between pre-service teachers' environmental education self-efficacy beliefs in terms of taking environmental education course or not, independent sample t-test was conducted and obtained results are presented in the table 3 below.

Table 3. T- test Outcome of Pre-Service Teachers' Environmental Education Self-Efficacy Beliefs Depending on Taking Environmental Education Course or Not.

\begin{tabular}{|c|c|c|c|c|c|c|c|c|}
\hline & \multicolumn{6}{|c|}{ Have You Taken an Environmental Education Course? } & \multirow[b]{3}{*}{$\mathrm{t}$} & \multirow[b]{3}{*}{$\mathrm{df}$} \\
\hline & \multicolumn{3}{|l|}{ Yes } & \multicolumn{3}{|l|}{ No } & & \\
\hline & $\mathrm{M}$ & SD & $\mathrm{N}$ & $\mathrm{M}$ & SD & $\mathrm{N}$ & & \\
\hline $\begin{array}{l}\text { Environmenta } \\
\text { Education }\end{array}$ & & & & & & & & \\
\hline $\begin{array}{l}\text { Self-Efficacy } \\
\text { Beliefs }\end{array}$ & 3.85 & .40 & 9 & 3.69 & .44 & 120 & 1.04 & 127 \\
\hline
\end{tabular}

As the table indicates, the results of the t-test analysis indicated that there is no significant difference between pre-service teachers' environmental education self-efficacy beliefs in terms of taking environmental education course or not $(\mathrm{t}(127)=1.04, \mathrm{p}=.30)$. In other words, pre-service teachers' environmental education self-efficacy beliefs who have taken environmental education course did not differ from pre-service teachers who have not taken environmental education course. In addition to this, to comprehend whether there is a significant difference between pre-service teacher's attitudes towards sustainability environment with regards to taking sustainability course or not, independent sample t-test was conducted and results are presented in the table 4 below.

Table 4. T- test Outcome of Pre-Service Teachers' Attitudes Towards Sustainable Environment Depending on Taking a Sustainability Course or Not.

\begin{tabular}{|c|c|c|c|c|c|c|c|c|}
\hline & \multicolumn{6}{|c|}{ Have You Taken a Sustainability Course? } & \multirow[b]{3}{*}{$\mathrm{t}$} & \multirow[b]{3}{*}{$\mathrm{df}$} \\
\hline & \multicolumn{3}{|c|}{ Yes } & \multicolumn{3}{|c|}{ No } & & \\
\hline & $\mathrm{M}$ & $\mathrm{SD}$ & $\mathrm{N}$ & $\mathrm{M}$ & $\mathrm{SD}$ & $\mathrm{N}$ & & \\
\hline $\begin{array}{l}\text { Attitudes } \\
\text { towards } \\
\text { Sustainable } \\
\text { Environment }\end{array}$ & 4.06 & .38 & 18 & 4.33 & .38 & 111 & -2.76 & 127 \\
\hline
\end{tabular}

As it can be inferred from the table, the results of the t-test analysis showed that there is a statistically significant difference between pre-service teachers' attitudes towards sustainable environment depending on having sustainability course or not $(t(127)=-2.76, p=.006)$. In other words, pre-service teachers' attitudes towards sustainable environment who have taken sustainability course did differ from pre-service teachers who have not taken sustainability course. The magnitude of the difference in the means was small but almost moderate (eta squared=.005).

Another test which is one-way ANOVA test was carried out to reveal whether there is a significant difference in pre-service teachers' environmental education self-efficacy beliefs in terms of grade level. The results are presented in the table below (Table 5). 
Table 5. One-way ANOVA Outcomes Regarding Participants' Environmental Education Self Efficacy Beliefs.

\begin{tabular}{|c|c|c|c|c|c|c|c|c|c|c|}
\hline & Groups & $\mathrm{N}$ & $\bar{x}$ & SD & $\begin{array}{l}\text { Group } \\
\text { Variance }\end{array}$ & $\begin{array}{l}\text { Sum of } \\
\text { Squares }\end{array}$ & $\mathrm{df}$ & $\begin{array}{l}\text { Mean } \\
\text { Square }\end{array}$ & $\bar{f}$ & $\mathrm{p}$ \\
\hline \multirow{9}{*}{$\begin{array}{l}\text { Environmental } \\
\text { Education } \\
\text { Self-Efficacy } \\
\text { Beliefs }\end{array}$} & 1st & 24 & 3.75 & .38 & Between & .21 & 3 & .07 & & \\
\hline & Grade & & & & Groups & & & & & \\
\hline & 2nd & 31 & 3.71 & .48 & & & & & & \\
\hline & Grade & & & & & & & & & \\
\hline & $3 \mathrm{rd}$ & 42 & 3.64 & .48 & Within & 25.29 & 125 & .20 & & \\
\hline & Grade & & & & Groups & & & & & \\
\hline & 4 th & 32 & 3.72 & .39 & & & & & & \\
\hline & Grade & & & & Total & 25.50 & 128 & & .35 & .79 \\
\hline & Total & 129 & 3.70 & .44 & & & & & & \\
\hline
\end{tabular}

Results show that there is no significant difference in pre-service teachers' environmental education self-efficacy beliefs according to grade level $[\mathrm{F}(3,125)=.35, \mathrm{p}=.789]$. For another inquiry about difference between pre-service teachers' sustainable environment attitudes in terms of grade level, one-way ANOVA test was carried out. The results are presented in the table below (Table 6).

Table 6. One-way ANOVA Outcomes Regarding Participants' Sustainable Environment Attitudes

\begin{tabular}{|c|c|c|c|c|c|c|c|c|c|c|}
\hline & Groups & $\mathrm{N}$ & $\bar{X}$ & SD & $\begin{array}{l}\text { Group } \\
\text { Variance }\end{array}$ & $\begin{array}{l}\text { Sum of } \\
\text { Squares }\end{array}$ & $\mathrm{df}$ & $\begin{array}{l}\text { Mean } \\
\text { Square }\end{array}$ & $\mathrm{f}$ & $p$ \\
\hline \multirow{6}{*}{$\begin{array}{l}\text { Attitudes } \\
\text { towards } \\
\text { Sustainable } \\
\text { Environment }\end{array}$} & $\begin{array}{l}\text { 1st } \\
\text { Grade }\end{array}$ & 24 & 4.35 & .23 & $\begin{array}{l}\text { Between } \\
\text { Groups }\end{array}$ & 1.76 & 3 & .58 & & \\
\hline & $\begin{array}{l}\text { 2nd } \\
\text { Grade }\end{array}$ & 31 & 4.41 & .37 & & & & & & \\
\hline & $\begin{array}{l}\text { 3rd } \\
\text { Grade }\end{array}$ & 42 & 4.32 & .43 & $\begin{array}{l}\text { Within } \\
\text { Groups }\end{array}$ & 18.21 & 125 & .14 & & \\
\hline & & 32 & 4.10 & .39 & & & & & & \\
\hline & Grade & & & & Total & 19.97 & 128 & & 4.02 & .009 \\
\hline & Total & 129 & 4.29 & .39 & & & & & & \\
\hline
\end{tabular}

Results show that there is a statistically significant difference in pre-service teachers' attitudes towards sustainable environment in terms of grade level $[\mathrm{F}(3,125)=4.02, \mathrm{p}=.009]$. The effect size, calculated using eta squared, was .08. Cohen (1988) classifies .01 as a small effect, .06 as a medium effect and .14 as a large effect. Thus, the actual difference in mean scores between the groups is large. In addition, post-hoc comparisons using Scheffe test indicated that the mean score for 2nd grade students $(M=4.41, S D=.37)$ was significantly different from 4 th grade students $(M=4.10, S D=.39)$. 1st grade students $(M=4.35, S D=.23)$ and 3rd grade students $(M=4.32, S D=.43)$ did not differ significantly from both 2 nd and 4 th grade students.

Last investigation of this study is to determine the relationship between pre-service teachers' environmental education self-efficacy beliefs and their attitudes towards sustainable environment. In order to detect this relationship, a Pearson's Product Moment Correlation analysis was implemented. The obtained results of this analysis are displayed in the following table (Table 7). 
Table 7. Pearson Product-Moment Correlation between Measures of Environmental Education SelfEfficacy Beliefs and Sustainable Environment Attitudes.

\begin{tabular}{lll}
\hline Measures & 1 & 2 \\
\hline (1) EESS & & $.24^{* *}$ \\
(2) SEAS & $.24^{* *}$ &
\end{tabular}

$\mathrm{N}=129$. EESS= Environmental Education Self-Efficacy Scale; SEAS= Sustainable Environment Attitude Scale. ${ }^{* *} \mathrm{p}<.01$

The relationship between pre-service early childhood teachers' environmental education selfefficacy beliefs (as measured by the EESS) and their attitudes towards sustainable environment (as measured by the SEAS) was investigated using Pearson product-moment correlation coefficient. Preliminary analyses were performed to ensure no violation of the assumptions of normality, linearity and homoscedasticity. Based on the results given in the table, there is a small, positive correlation between the two variables $(r=.246, n=129, \mathrm{p}<.01)$.

\section{CONCLUSION AND DISCUSSION}

The purpose of this study was to explore the relationship between pre-service early childhood teachers' environmental education self-efficacy beliefs and their attitudes toward sustainable environment. The existing literature demonstrates that environmental education and sustainable environment were examined separately but, in this study, it is aimed to analyze whether there is a relationship between each other. Apart from the relationship, as mentioned in the previous sections, this study looks for the differences among groups in terms of grade level and taking environmental or sustainability courses or not. In related literature, Tomas et al. (2015) revealed that pre-service teachers find sustainability relevant to their learning and they need sustainability education to teach their students. Besides, Dyment et al. (2014) found that early childhood educators had a powerful understanding, sense of knowledge, and confidence in the application of sustainability. In this research, pre-service early childhood education teachers indicated medium level of self-efficacy in environmental education and positive attitudes toward sustainable environment. Likewise, Aydin and Ünald1 (2013) found that pre-service teachers in Turkey had high positive attitudes towards sustainable environment and, in this study, female pre-service teachers had higher positive attitudes than their male counterparts. In addition to this, Çimen and Benzer (2019) conducted a study to examine pre-service science and elementary teachers' attitudes towards sustainable environment and they found that those pre-service teachers had positive attitudes towards sustainable environment. As Aydın and Ünaldı (2013) revealed, Çimen and Benzer (2019) found that female preservice teachers had higher attitudes than male pre-service teachers. Besides, Uludağ, Karademir and Cingi (2017) investigated behavior levels of pre-service early childhood teachers on sustainable environment and results of this study showed that mean scores of female pre-service teachers about sustainable environment was quite higher than male pre-service teachers scores. Surprisingly, despite a significant difference was found in pre-service teachers' sustainable environment attitudes in terms of taking sustainability course or not, there was no difference in environmental education self-efficacy beliefs among pre-service teachers regarding taking environmental education course or not. This might result from that sustainability might be more complicated issue than environmental education. More precisely, students may have less knowledge about sustainability unless they take sustainability course. On the other hand, another result of this study revealed that there is no significant difference in pre-service teachers' environmental education self-efficacy beliefs in terms of grade level but there is a statistically significant difference in pre-service early childhood teachers' 
attitudes towards sustainable environment regarding grade level. With respect to this, 2nd grade students have more positive attitudes toward sustainability than other students. Based on Cohen's (1988) classification, the accrual difference in mean scores between the groups is quite large. Similarly, Aydın and Ünaldı (2013) revealed that there was a meaningful difference in pre-service teachers' attitudes towards sustainable environment in terms of grade level. In this study first and fourth grade students differed from each other regarding their sustainable environment attitudes (Aydın \& Ünaldı, 2013). Moreover, Çimen and Benzer (2019) indicated that first grade pre-service teachers differed from second graders and there is a difference between second grade students and fourth graders with respect to attitudes towards sustainable environment. Because there is an environmental education course in the second year, second grade students might have higher attitudes towards sustainable environment than their counterparts (Çimen \& Benzer, 2019). However, results of the study conducted by Uludağ, Karademir and Cingi (2017) indicated that preservice early childhood teachers did not differ from each other in terms grade level. The last inquiry of this study elicited a small relationship between pre-service teachers' environmental education self-efficacy beliefs and their attitudes toward sustainable environment. As mentioned at the beginning of the study, environmental education and sustainability are interrelated concepts. Eventually, having regard to this result, there is a positive correlation between pre-service early childhood teachers' environmental education self-efficacy beliefs and their attitudes towards sustainable environment. Lastly, as a suggestion, further research can be conducted so as to deeply investigate pre-service teachers' attitudes toward sustainable environment and their beliefs about environmental education since this research does not look for reasons behind their thoughts and obtaining their ideas through qualitative studies might be beneficial for other research and implementation or organization of sustainability and environmental education courses.

\section{REFERENCES}

Aydın, F., \& Ünaldı, Ü. E. (2013). Coğrafya öğretmen adaylarının sürdürülebilir çevreye yönelik tutumları. Kalem Ĕ̆itim ve İnsan Bilimleri Dergisi, 3(1), 11-42.

Ballantyne, R., \& Packer, J. (2005). Promoting environmentally sustainable attitudes and behaviour through free-choice learning experiences: What is the state of the game? Environmental Education Research, 11(3), 281-295.

Bixler, R. D., Carlisle, C. L., Hammitt, W. E., \& Floyd, M. F. (1994). Observed fears and discomforts among urban students on field trips to wildland areas. The Journal of Environmental Education, 26(1), 24-33.

Boileau, E. Y. S. (2014). Young Voices: The challenges and opportunities that arise in early childhood environmental education research. Canadian Journal of Environmental Education (CJEE), 18, 142-154.

Brundtland, G. H. (1987). Report of the world commission on environment and development: "Our common future.". United Nations.

Carson, R., \& Kelsh, N. (1998). The sense of wonder. New York, USA: Harper Collins Publishers.

Checkley, K. (1997). The first seven... and the eighth: A conversation with Howard Gardner. Educational Leadership, 55(1), 8-13.

Cohen, J. (1998). Statistical power analysis for the behavioral sciences. Hillsdale, NJ:Erlbaum

Crim, C., Desjean-Perrotta, B., \& Moseley, C. (2008). Partnerships gone wild: Preparing teachers of young children to teach about the natural world. Childhood Education, 85(1), 6-12.

Cutter-Mackenzie, A., \& Smith, R. (2003). Ecological literacy: The 'missing paradigm 'in environmental education (part one). Environmental Education Research, 9(4), 497-524. 
Çimen, H., \& Benzer, S. (2019). Fen bilgisi ve sınıf öğretmen adaylarının sürdürülebilir çevreye yönelik tutumlarının incelenmesi. İnsan ve İnsan, 6(21), 525-542.

Davis, J. (2009). Revealing the research 'hole' of early childhood education for sustainability: A preliminary survey of the literature. Environmental Education Research, 15(2), 227241.

De Winter, J. F. C., \& Dodou, D. (2010). Five-point likert items: T test versus Mann-WhitneyWilcoxon. Practical Assessment, Research, and Evaluation, 15(1), 11.

Duhn, I. (2012). Making 'place' for ecological sustainability in early childhood education. Environmental Education Research, 18(1), 19-29.

Dyment, J. E., Davis, J. M., Nailon, D., Emery, S., Getenet, S., McCrea, N., \& Hill, A. (2014). The impact of professional development on early childhood educators' confidence, understanding and knowledge of education for sustainability. Environmental Education Research, 20(5), 660-679.

Edwards, S., \& Cutter-Mackenzie, A. (2013). Pedagogical play types: What do they suggest for learning about sustainability in early childhood education? International Journal of Early Childhood, 45(3), 327-346.

Effeney, G., \& Davis, J. (2013). Education for sustainability: A case study of pre-service primary teachers' knowledge and efficacy. Australian Journal of Teacher Education, 38(5), 32-46.

Ernst, J., \& Tornabene, L. (2012). Pre-service early childhood educators' perceptions of outdoor settings as learning environments. Environmental Education Research, 18(5), 643-664.

Evans, N., Whitehouse, H., \& Hickey, R. (2012). Pre-service teachers' conceptions of education for sustainability. Australian Journal of Teacher Education, 37(7), 1-12.

Fraenkel, J. R., Wallen, N. E., \& Hyun, H. H. (2013). How to design and evaluate research in education. New York: McGraw-Hill.

Independent Earth Charter Commission. (2012). The earth charter. Retrieved from http://www.earthcharterinaction.org/content/pages/Read-the-Charter.html

Liu, L. (2011). Where in the world of sustainability education is US geography? Journal of Geography in Higher Education, 35(2), 245-263.

Louv, R. (2008). Last child in the woods: Saving our children from nature-deficit disorder. Chapel Hill, NC: Algonquin.

Mustard, F. (2000). Early childhood development: The base for a learning society. In HRDC/OECD Meeting, December (Vol.7). Retrieved from http://www.oecd.org/education/school/31551283.pdf

Müsteşarlığı, T. Ç. (1990). Türkiye Çevre Eğitim ve Öğretimi Ulusal Çevre Stratejisi ve Uygulama Planları Semineri. Ankara: Devlet Planlama Teşkilatı

Özer, U. (1993). Yükseköğretimde çevre için eğitim ve çevre eğitimi. Ankara: Çevre Vakfı Yayını.

Özlü, G., Keskin, M. Ö., \& Gül, A. (2013). Çevre eğitimi öz-yeterlik ölçeği geliştirilmesi: Geçerlik ve güvenirlik çalışması. Gazi University Journal of Gazi Educational Faculty (GUJGEF), 33(2).

Pearson, E., \& Degotardi, S. (2009). Education for sustainable development in early childhood education: A global solution to local concerns. International Journal of Early Childhood, 419, 97111.

Rutter, M. (2002). The interplay of nature, nurture, and developmental influences: The challenge ahead for mental health. Archives of General Psychiatry, 59(11), 996-1000.

Sadik, F. (2013). Investigating environmental attitudes and knowledge levels of teacher candidates in terms of different variables. Pegem Ĕ̆gitim ve Öğretim Dergisi, 3(4), 69-82.

Simmons, D. (1998). Using natural settings for environmental education: Perceived benefits 
and barriers. The Journal of Environmental Education, 29(3), 23-31.

Symons, G. (2008). Practice, barriers and enablers in esd and ee: A review of the research. Shrewsbury: Council for Environmental Education.

Tavsancıl, E. (2006). Tutumların ölçülmesii ve SPSS ile veri analizi.(3. Baskı). Ankara: Nobel Yayıncılık. The North American Association for Environmental Education. (2010). Early childhood environmental education programs: Guidelines for excellence. Retrieved from https://naaee.org/eepro/publication/early-childhood-environmental-educationprogramsguidelines-excellence

Tomas, L., Girgenti, S., \& Jackson, C. (2017). Pre-service teachers' attitudes toward education for sustainability and its relevance to their learning: Implications for pedagogical practice. Environmental Education Research, 23(3), 324-347.

Torquati, J., Cutler, K., Gilkerson, D., \& Sarver, S. (2013). Early childhood educators' perceptions of nature, science, and environmental education. Early Education EDevelopment, 24(5), 721-743.

Ull, M. A., Martínez-Agut, M. P., Piñero, A., \& Aznar-Minguet, P. (2014). Perceptions and attitudes of students of teacher-training towards environment and sustainability. ProcediaSocial and Behavioral Sciences, 131, 453-457.

Uludağ, G., Karademir, A. H., \& Cingi, M. A. (2017). Okul öncesi öğretmen adaylarının sürdürülebilir çevreye ilişkin davranış düzeylerinin incelenmesi. Mehmet Akif Ersoy Üniversitesi Ĕ̆itim Fakültesi Dergisi, 1(41), 120-136.

Wilson, R. A. (2009). The color green: A 'go' for peace education. Exchange: The Early Childhood Leaders' Magazine Since 1978, (187).

Yıldız, Ş. (2011). Conceptual understanding and attitudes of teachers, prospective teachers and students towards sustainable environment [Master's thesis, Dokuz Eylul University]. Retrieved from: http://acikerisim.deu.edu.tr/xmlui/handle/12345/7151 